\title{
The Effect of Racetrack Game Using Numbers Line towards the Numerical Ability of Kindergarten
}

\author{
Syafdaningsih \\ Early Childhood Education Department \\ University of Sriwijaya \\ Indralaya, Indonesia \\ syafdaningsihsyafar@gmail.com
}

\author{
Hestira Rahamaliyana \\ Early Childhood Education Department \\ University of Sriwijaya \\ Indralaya, Indonesia \\ hestirarahamaliyana@gmail.com
}

\begin{abstract}
The effect of Racetrack game using numbers line Game towards the numerical ability of children group $B$ at Persatuan Wanita Patra Palembang Kindergarten research was held by occurring the type of research Pre-Experiment with One Shoot Case Study design, to determine the effect of race track game using the numbers line towards numeracy skills in children. The sampling technique that had been used was purposive with consideration numeracy are still low in class B3 of the other classes, data collection using the test works. The results of the analysis of $t_{\text {count }} 5,65 \geq t_{\text {table }}=1.72, \alpha=0.05$ so that there is an effect of race track game using numbers line towards children numerical ability for Group B in Persatuan Wanita Patra Palembang Kindergarten. This is evident from 23 children: 13 children $(56.52 \%)$ are in the category of Developed Very Nicely (DVN) indicator appears mentioned numbers 1 to 20; The next 9 children $(\mathbf{3 9 . 1 3 \%}$ ) are in the category of Developed as Expected (DAE) with indicator counting result of the addition are 2 sets of pictures of cars, motorcycles, and bicycles up to 20; while 6 children $(\mathbf{2 6 . 0 9 \%})$ are in the category of Start to Developing (STD) indicator calculates the result of reduction are 2 sets of pictures of cars, buses and public transit cars to 20. The weakness of this study is still dependent on the children's teachers to help answer results in a reduction because children do not understand. For further research suggested developing a number line media for numeracy activities and increase opportunities for children to practice counting himself.
\end{abstract}

Keywords: racetrack, game, numbers line, numeracy, early childhood education

\section{INTRODUCTION}

Children's world is playing the world which contains spontaneity and joyful. Playing is an effective way for children to understand. Children are able to improve skills in many aspects. Those aspects are the linguistic, cognitive, physical and social aspect. According to [1], playing can train the function of mentality, such as thinking, imagining and remembering. At the age of 5-6, the child enjoys playing activity because all aspects of children's development are growing and developing, one of them is the cognitive aspect. Cognitive development of a 5-6-year-old child is in the stage of pre-operational that showed the ability to do object and event representation mentally through semiotic function, the same as children's numerical activity. The child has not capable to think concretely, especially with addition and subtraction.
For example, the case in Persatuan Wanita Patra Kindergarten, with an observation that has been done on 5th until 16th of October 2015, on the numerical learning process, teacher and student have counting activity for number one to twenty, it has to be done before the exact study activity occurred. The counting activity was held together with the teacher and many students. While counting together, only 12 out of 20 children that counted the numbers one until twenty and eight of them were not saying any numbers or even getting distraction with their nearby friends who did not understand too.

On 12th of October 2015, students learned the sub-theme "my daily needs". The teacher wrote numbers on a whiteboard, then the children wrote down those numbers into their notebook and solving the calculation. After the children had answered the questions that had been written previously in whiteboard, teacher and children were answering the questions together. Only five out of 18 children that successfully answered the questions.

One of the reason children could not concentrate with the learning is because they were distracted enjoying their own activity, like chatting with a friend or playing by themselves rather than paying attention to their teacher while the class was occupied. At the numerical learning, the teacher taught the lesson in an abstract way rather than concrete media or real things. Teacher was just writing the numbers on the whiteboard and saying the numbers that would be counted, for example, " 15 plus 3, please keep in your head 15 and your fingers 3, now count how it will be?", and next children just wrote down the problems on the notebook. This circumstance actually could not be possible to be done in children, because children still could not answer the numbers just by thinking the problem solving only in their mind. The regulation from Republic Indonesia Minister of Education and Culture Number 146 The year 2014 had stated that cognitive development on that age (five up to six years old) already able to understand the numerical concept.

Children's cognitive development had not been reached due to the uninteresting and boring teaching system for children, therefore they chose to do something else like playing instead of paying on the study. Even more, parents' participation was not supporting on learning process about counting with the result that children's numerical ability was hampered. Parents' role and teacher's learning system supposed to be correctly presented for helping the development of children. One of the 
strategies for developing children's numerical ability is by doing playing activity called race track using a number line.

The race track game was introduced by Martin Gardner on 1973 in " Mathematical Game" with American scientific approach. [5] stated that mathematical racetrack is a board game like "track". Racetrack game represents "racing game" with rotating the wheel of numbers and on each of the "routes" has a question of the problem in "flashcards". Those researchers also used additional media such as number line for simplified the children to answer the question in "flashcards".

Racetrack game using number line has more advantage than the other games. This game can be combined with learning material from flash cards usage. Racetrack game that had made by the researchers was huge or in another word "in life-size version" that the children could involve physical motion or in this case step to it, according to numbers that stopped from numbers wheel for developing counting numbers. Numbers game also can help children understanding the concept of addition and subtraction.

While playing the numbers line, children can see and reveal by themselves how much the results of addition and subtraction by moving car toy or just stepping. Move forward if it is an addition or moves backward if it is subtraction. Children can see the resulting number from addition or subtraction by stopping on car toy's arrow. It can increase children's understanding of numerical lesson through the race track game by using the number line. Thus, the researcher wants to use race track game by using number line in numerical learning for students. It is predicted can influence children's numerical ability.

Similar to previous research from Joanne Romjue, McLaughlin, and Mark "The Effects of Reading Racetrack and Flashcards for Teaching of Sight Words". The result shows that reading race track and the flash card had effect significantly to the children's ability of reading had proven by the results before and after the treatment.The first member of game answered eight words correctly and 6 false answers in the first list, and then he said 11 right answers and 3 false on the second list, on the third list he answered 9 rights and 5 falsies, and in the fourth list, he successfully answered 13 rights from 14 words.

The second member, on the first list, answers seven words correctly and seven wrong answers. And then, a second list, seven rights, and seven falsies. At the third list, she answered 10 right answers and four wrong answers. And the last in the fourth list, she was able to read 14 words without any mistakes.

It can be inferred that the using of racetrack will have a better effect on the numerical ability for Group B in Persatuan Wanita Patra Palembang Kindergarten. From the problems above, the writers want to make a research which titled "The Effect of Racetrack Game Using Numbers Line towards the Numerical Ability of Children Group B in Persatuan Wanita Patra Palembang Kindergarten".

From those descriptions of background above, it can be formulated that the problem in this research is: "Is there any effects of race track game using numbers line towards the children numerical ability on Group B Persatuan Wanita Patra Palembang kindergarten?".

The purpose of this research is for knowing if there is an effect of race track game using numbers line to children's numerical ability or there is nothing. This research hopefully can give advantages, namely: 1) Children can understand the numerical concept through race track game using numbers line; 2) Increasing teacher's performance and this research become the base for teacher for giving various learning activity; 3) With this research, Persatuan Wanita Patra Palembang Kindergarten can develop the learning process for making children's achievement better; 4) For important information on dedicating for the knowledge that had been achieved, and can become the reference for further research.

Every child has intelligence, in the learning process the children supposed to develop their intelligence. [12] divided intelligence into eight types which are linguistic intelligence, visual-spatial intelligence, logical-mathematical intelligence, kinesthetic intelligence, musical intelligence, intrapersonal intelligence, interpersonal intelligence and naturalistic intelligence. Numerical ability included in logicalmathematical intelligence. It can be possible because of in logical-mathematical intelligence case, children must be capable of processing numbers or using rational logic, which basically involves with numbers and logic.

Ref. [12] stated that numerical ability is a capability that children have for developing their skills. Development characteristics start from the nearest environment from the children, accordance with the ability development for increasing the understanding for acknowledging numbers, which related to addition and subtraction. [6] addressed that counting is an exciting way for comprehending numbers concept. [14] said numerical ability is the children's competence for apprehend numbers concept that connected with recognizing the addition and the subtraction, and also making correspondence between one object to the other object. The permendikbud year 2014 about 2013 curriculum of early childhood stated that 5 up to 6 years old children can say the numbers of things by counting and mention the numbers if someone shows them the numbers.

Based on those opinions above, the numerical ability is a capability of children for answering questions which embody in numbers concept material, making correspondence between one object to another object, addition, and subtraction.

Every child likes playing activity. Playing activity can be occurred by a game. Type of game can be matched with children's age and needs so it can optimize children's growth and development.

Ref. [8] mentioned that game is a form of recreation which intends for having enjoyments, spending leisure time, or doing mild exercise. In the opinion of [7], the game is an education tool because it gives the satisfaction, excitement, and happiness.

Corresponded to those points, a game is an activity which creates the excitement and significant satisfaction. One of the games for children is racetrack game. Racetrack game represents about race game by throwing a dice or spinning the 
numbers wheel and each road route has a question that has been kept on a flash card. Cited to [5] a math racetrack is a game board like a track that simulates a race track. A match race track consisted of 28 spaces which written math fact or numerals to be learned. Next, Beveri edge, et al. stated "a math racetrack is a drill and practice procedure where known and unknown fact is placed on a sheet of paper like an oval racetrack.

By the opinions above it can be inferred that race track is a board game like track which simulates race area that contains 28 spaces filled with mathematics problem in a piece of paper like racetrack oval which is played by two or more than two players.

Many children have difficulties for understanding counting concept, specifically in addition and subtraction. Counting lesson will be more interesting if it is wrapped in a game, therefore, children can understand what addition and subtraction faster than before. Numbers line media can help teachers for delivering counting learning.

Ref. [4] said that numbers line is a straight line which is signed by range dots from one dot to another dot with similar length. ". [4] said that numbers line is a straight line that has dots which have similar range one to another, a dot is written a number orderly from the smallest negative on the left side of zero up to the largest positive number on the right side of zero

Based on those opinions, numbers line is a straight line which has dots, in each dot is written one real number and one dot to another are similar in range length.

Thus, race track game using numbers line is a board game like track which stimulates racing arena that consisted of 28 spaces of mathematical problem placed on a piece of paperplayed by two or more than two players using numbers line for helping numerical activity.

\section{MethodS}

Before This research method is quantitative with pseudo experiment method using "one-shot case study" design. The purpose for choosing this design is for observing the effect of race track game using numbers line towards the numerical ability of student in Group B Persatuan Wanita Patra Palembang.

According to [12], the design can be seen in Table 1 below.

$$
\text { TABLE I. RESEARCH DESIGN }
$$

\begin{tabular}{|c|c|}
\hline Treatment & Posstest \\
\hline $\mathrm{X}$ & $\mathrm{O}$ \\
\hline
\end{tabular}

Explanations:

$\mathrm{X}$ : Treatments for learning with the help of race track game using numbers line.

$\mathrm{O}$ : Treatments Test which is given after learning with the help of race track game using numbers line.

Data collecting in this research is by the test. Test for knowing the effect of race track using numbers line towards children's numerical ability is confirmed with children's numerical ability indicators.
The test will occur after the race track using numbers line treatments have been already given. This research used behavioral test.

The last valuation for each test will be calculated by sums up achieved value for each question and converts it to a score range $0-100$, with this following rule:

$$
\text { Value }=\frac{\text { achieved score }}{\text { total score }} \times 100 \%
$$

Normality test purposes for knowing whether data are distributed normally or no.Thus, for the hypothesis test, the parametric statistic is used and if data does not distribute normally, it will occur another type of test called nonparametric statistic. For testing the normality of data, the calculation uses Chi-Square with confidence level 95\% $(\alpha=$ 0.95) for this formulation :

$$
\mathrm{X}^{2}=\left(\frac{f_{0-f_{h}}}{f_{h}}\right)
$$

Explanation:

$\mathrm{X}^{2}=$ Chi-Square

$\mathrm{f}_{0}=$ Observed Frequency

$\mathrm{f}_{\mathrm{h}}=$ Expected Frequency

Criteria for calculation is if $\mathrm{x}_{\text {count }}^{2}<\mathrm{x}^{2}$ table, then data distribution is normal, and for the opposite, it can be stated that it is not normal.

Data hypothesis test is executed by t-test because the researchers desire to know if there is an effect of race track game using numbers line towards the numerical ability of children in Group B Persatuan Wanita Patra Palembang Kindergarten. Statistic Test formulation is shown below:

$$
\mathrm{t}=\frac{\bar{X}_{1-\bar{X}_{0}}}{-\frac{S d}{\sqrt{n}}}
$$

Explanation :

$$
\begin{array}{ll}
\mathrm{t} & =\text { Value of } \mathrm{t} \\
\bar{X}_{1} & =\text { Mean after treatment } \\
\bar{X}_{0} & =\text { Minimum Completeness Criteria } \\
\mathrm{Sd}_{1} & =\text { Standard deviationbefore treatment } \\
\mathrm{Sd}_{2} & =\text { Standard deviationafter treatment } \\
\mathrm{n} & =\text { data }
\end{array}
$$

Therefore, statistic hypothesis formulation for this research is [2]:

$$
\begin{gathered}
H_{0}: \mu_{1}=\mu_{0} \\
\mathrm{H}_{1}: \mu_{1}>\mu_{0}
\end{gathered}
$$

\section{Explanation:}

$\mathrm{H}_{0}$ : There is no effect of race track game using numbers line towards the numerical ability of students in Grop B Persatuan Patra Wanita Palembang Kindergarten. 
$\mathrm{H}_{\mathrm{a}} \quad$ : Here is an effect of race track game using numbers line towards the numerical ability of students in Grop B Persatuan Patra Wanita Palembang Kindergarten

The criteria for the test, if $t_{\text {count }}<t_{\text {table }} \mathrm{H}_{0}$ is accepted and $\mathrm{H}_{\mathrm{a}}$ is rejected, the opposite which $t_{\text {count }}>t_{\text {table }} \mathrm{H}_{0}$ is rejected and $\mathrm{Ha}$ are accepted. Meanwhile,t-table can be gotten from student's t distribution list with the degree of freedom $(\mathrm{dk}) \mathrm{n}$ 1 .

\section{RESULT AND DISCUSSION}

Research results are based on by valuing posttest of children's numeracy. This research is done by six times. And then, the final value of post-test is achieved. These are the recapitulation of numeracy ability from Table 2 below:

TABLE II. FREQUENCY DISTRIBUTION OF NUMERACY ABILITY

\begin{tabular}{|c|c|c|c|}
\hline Category & $\begin{array}{c}\text { Value } \\
\text { Range }\end{array}$ & Frequency & Percentage \\
\hline DAE & $82-100$ & 13 & 56.52 \\
\hline DVN & $63-81$ & 7 & 30.43 \\
\hline STD & $44-62$ & 2 & 8.70 \\
\hline HND & $25-43$ & 1 & 4.35 \\
\hline
\end{tabular}

On Table II it can be seen that an average number of numerical ability is proper for the average students' score which in the first class interval $25-43$ (Have not Developed category). There is one student out of 23 or as much as $4.35 \%$ which is in this interval. For 44-62 interval (Start to Developing category), there are 2 children out of 23 or $8.7 \%$. For 63-81 interval (Developed as an Expected category), there are 7 students out of 23 or as much s $30.43 \%$. And for the 82 100 interval are 13 children out of 23 , or $56.52 \%$ (Developed Very Nicely). For further explanation, it can be shown in this histogram on Figure 1 below.

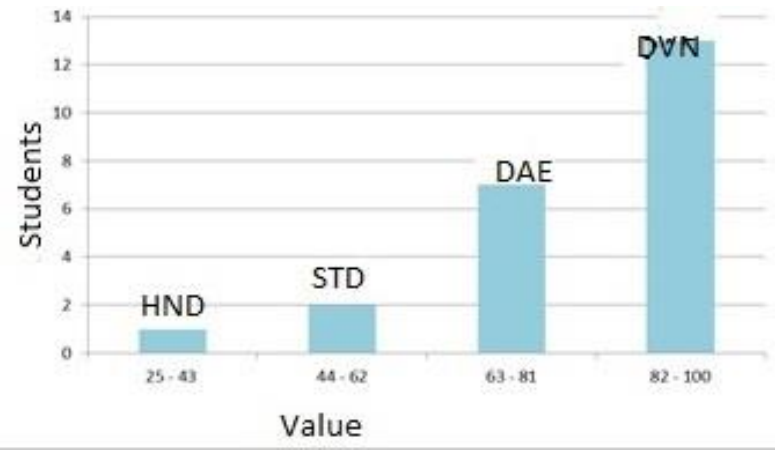

Fig. 1. Children's Numerical Ability in PWP Palembang Kindergarten

And then, normality test is occurred for knowing if data that will be analyzed is distributed normally or no. In this case, researcher test the normality with Chi-square test. According to Arikunto [2] hypothesis formulation that is used for analyzing data's normality with criteria, $\chi^{2}$ count $\leq \chi^{2}$ tabledistributed normallyand $X^{2}$ count $\geq X^{2}$ table distributed abnormally. From Chi Square test $\left(\chi^{2}\right)$ with $\mathrm{n}=23$ and confidence level 95\%, and $\mathcal{X}_{\text {count }}^{2}=2.41$ obtained chi square $\left(\mathcal{X}^{2}\right)=33.9$. It can be concluded that data is distributed normally.

After normality test is obtained, the next test for data analyzing is t-test. Since this research purpose for knowing if there is an effect of race track game using numbers line to children's numerical ability, there are steps that have to be followed for achieving the conclusion from hypothesis:

- From Hypothesis formulation:

$\mathrm{H}_{0}$ : There is no effect of race track game using numbers line towards the numerical ability of students in Grop B Persatuan Patra Wanita Palembang Kindergarten

$\mathrm{H}_{\mathrm{a}}$ : There is an effect of race track game using numbers line towards the numerical ability of students in Grop B Persatuan Patra Wanita Palembang Kindergarten

- Obtaining $\mathrm{t}_{\text {count }}$

Before executing t-test, the first thing to do is calculating the mean of the daily scoring value of children and standard deviation of children's daily score. Then, comparing mean and standard deviation of posttest. This calculation below is t-count calculation:

1) $t$-test calculation

$$
\begin{gathered}
\mathrm{t}=\frac{\bar{X}_{1-\bar{X}_{0}}}{\frac{S d}{\sqrt{n}}} \\
\mathrm{t}=\frac{82,9-63}{\frac{16,5}{4,69}} \\
\mathrm{t}-\operatorname{count}=5.65
\end{gathered}
$$

2) Determining $t_{\text {table }}$

$\mathrm{t}_{\text {table }}$ is determined from $\mathrm{t}$-distribution table with probability $(1-\alpha)$ and $d k=(n-1) d k=(23-1)=22$, and degree of freedom $\alpha$ $=0.05$. So it can be achieved t-table $(0.95: 22)=1.72$.

\section{3) Test Criteria}

Test criteria of the hypothesis are: rejects $\mathrm{H} 0$ if $\mathrm{t} \geq \mathrm{tl}-\alpha$ and accepts $\mathrm{Ha}$ in the opposite. For making conclusions based on these criteria: if the value of $t_{\text {count }} \leq t_{\text {table }} H_{0}$ is accepted and $\mathrm{H}_{\mathrm{a}}$ is rejected. If $\mathrm{t}_{\text {count }} \geq \mathrm{t}_{\text {table }} \mathrm{H}_{0}$ is rejected $\mathrm{H}_{\mathrm{a}}$ is accepted. Based on the calculation of t-test, there is a result where $t_{\text {count }}$ 5,65 and $t_{\text {table }} 1,72$. Based on that result, it can be concluded that $\mathrm{H}_{\mathrm{a}}$ is accepted and $\mathrm{H}_{0}$ is rejected. It can be inferred that there is an effect of race track game using numbers line towards children's numerical ability of Group B in Persatuan Wanita Patra Wanita Palembang Kindergarten.

\section{CONCLUSION AND SUGGESTION}

\section{A. Conclusion}

According to from research results, it can be concluded that there is an effect of race track game using numbers line towards children's numerical ability of Group B in Persatuan Wanita Patra Wanita Palembang Kindergarten.

This is can be shown by the result that presents $t_{\text {count }}>t_{\text {table }}$. The value of $t_{\text {count }} 5.65$ and $t_{\text {table }} 1.72$. Thus $\mathrm{H}_{\mathrm{a}} \mathrm{is}$ accepted and $\mathrm{H}_{\mathrm{o}}$ is rejected. The learning process with race track game using numbers line is occurred without any concerned of students 
that they were actually studying about mathematics, due to the excitements from the game. Therefore, the numerical activity can be so much exciting to be learned.

\section{B. Suggestions}

Based on the research that had been done, it is suggested for teachers for applying race track game using in learning activity so that it will not be boring. And whenever applying race track game using numbers line, it is expected that teachers cooperate and help each other, for making the learning process still in control.

.For the next researcher, it is suggested for developing the numbers line media for numerical activity and enhance the chances for children to train themselves in numerical skills.

\section{REFERENCES}

[1] Arifin, Zainal. 2011. Evaluasi Pembelajaran. Bandung: PT Remaja Rosdakarya.

[2] Arikunto,Suharsimi, 2013. Prosedur Penelitian, Suatu Pendekatan Praktik. Jakarta: PT Rineka Cipta.

[3] Asfandiyar, Andi Yudha, 2012. Creative Parenting Today. Jakarta: PT Mizan Pustaka.

[4] Dewi, Ike Ligasari., 2011. Penggunaan Media Garis Bilangan Untuk Meningkatkan Kemampuan Berhitung Bilangan Bulat Pada Siswa Kelas
IV SDN 1 Karangduren klaten Tahun Pelajaran 2010/2011. Skripsi. Surakarta: Universitas Sebelas Maret.

[5] Ehlers, Emily., dkk. 2012. The Differential Effects Of Direct Instruction Flashcard and Math Racetrack on Number Identification for Three Preschool Students With Disabilities. Academic Research International., 3 (2): 286.

[6] Ismayani, Ani. 2013. Fun Math With Children. Jakarta: Media Komputindo

[7] Mutia, Diana. 2010. Psikologi Bermain Anak Usia Dini. Jakarta:Kencana Prenada Media Group.

[8] Purnomo, Sunyo Adji dan Ranni Novianty. 2013. 50 Games for Fun Learning and Teaching. Bandung:CV Yrama Widya.

[9] Putra, Sitiatava Rizema. 2013. Desain Evaluasi Belajar Berbasis Kinerja. Jogjakarta : DIVA Press

[10] Romjue, Holly R., McLaughlin dan Mark Derby., 2011. The Effects of Reading Racetrack and Flashcards for Teaching of Sight Words. Academic Research International., 1(2):134.

[11] Septian, Sarah. 2015. Pengaruh Permainan Puzzle Terhadap Kemampuan Mengenal Bentuk Geometri Pada Anak Kelas B1 Di TK Nurul Hidayah Palembang. Skripsi. Indralaya : Universitas Sriwijaya.

[12] Sugiono.2012. Metode Penelitian Kombinasi (Mixed Methods). Bandung:Penerbit Alfabeta.

[13] Susanto, Ahmad. 2012. Perkembangan Anak Usia Dini: Pengantar Dalam Berbagai Aspeknya. Jakarta: Kencana Prenada Media Group.

[14] Utomo, Islamiah Arta., 2015. Pengaruh Strategi Bermain Terhadap Kemampuan Berhitung Dalam Pembelajaran Konsep Penjumlahan Anak Di Kelas B1 TK IT Izzuddin Palembang. Skripsi. Inderalaya : Universitas Sriwijaya. 